\title{
Karakteristik Sifat Kualitatif Kambing Lokal di Kabupaten Bengkalis
}

\author{
(Characteristics of Qualitative Traits of Local Goat in Bengkalis Regency)
}

\author{
Destomo A, Batubara A, Elieser S \\ Loka Penelitian Kambing Potong, PO Box 1 Sungai Putih, Galang, Sumatera Utara 20585 \\ alfiandestomo@gmail.com
}

\begin{abstract}
Indonesian local goat is one source of animal protein. This study aims to identify the qualitative traits of local goats in Bengkalis Regency, Riau. Qualitative traits can be used characterized goats into specific breed. This research was conducted in four subdistricts in Bengkalis Regency (Bantan, Bengkalis, Siak Kecil, and Bukit Batu) with 110 samples of goats. Data were obtained by observation of coat color pattern, shape of horn, ear shape, face line, and back line. Data was tabulated and processed descriptively. The results of descriptive analysis of qualitative traits showed that the most widely found color pattern is the black-brown mixture with the most dominant brown color. The shape of the horn is mostly found as curved upward and the type of ears is upright. The face and back line are generally straight. The qualitative traits of local goats in Bengkalis Regency resembles the qualitative nature of Kacang goats and Peranakan Ettawah goats, respectively.
\end{abstract}

Key Words: Local Goat, Qualitative Traits, Bengkalis Regency

\begin{abstract}
ABSTRAK
Kambing lokal Indonesia merupakan salah satu sumber protein hewani. Penelitian ini bertujuan untuk mengidentifikasi sifat kualitatif pada kambing lokal di Kabupaten Bengkalis, Provinsi Riau. Sifat kualitatif dapat mencirikan kambing ke dalam galur tertentu. Penelitian ini dilaksanakan di empat kecamatan (Bantan, Bengkalis, Siak Kecil dan Bukit Batu) di Kabupaten Bengkalis dengan jumlah sampel 110 ekor kambing. Data diperoleh dengan observasi pola warna, bentuk tanduk, bentuk telinga, garis muka dan garis punggung. Data ditabulasi dan diolah secara deskriptif. Hasil analisis deskriptif sifat-sifat kualitatif menunjukkan pola warna yang paling banyak ditemukan adalah campuran hitam-cokelat dengan warna cokelat yang paling dominan. Bentuk tanduk paling banyak ditemukan melengkung ke atas dan tipe telinga tegak. Garis muka dan garis punggung pada umumnya berbentuk lurus. Sifat kualitatif kambing lokal di Kabupaten Bengkalis menyerupai sifat kualitatif pada kambing Kacang dan kambing Peranakan Ettawah.
\end{abstract}

Kata Kunci: Kambing Lokal, Sifat Kualitatif, Kabupaten Bengkalis

\section{PENDAHULUAN}

Kambing dan domba merupakan penghasil daging yang merupakan sumber protein hewani selain sapi, kerbau dan unggas. Selain memenuhi kebutuhan dalam negeri, kambing dan domba juga memiliki peluang pemasaran hingga ke negara tetangga seperti Malaysia, Brunei Darussalam dan negara-negara Timur Tengah. Peluang pasar yang besar ini dapat menjadikan kambing dan domba sebagai salah satu sumber pendapatan negara. Namun kendala yang dihadapi adalah kebutuhan dalam negeri yang belum dapat terpenuhi sepenuhnya, akibat rendahnya produktivitas dan kualitas ternak kambing dan domba di Indonesia sehingga perlu dilakukan peningkatan produktivitas dan kualitas kambing dan domba di Indonesia. 
Menurut data BPS (2016) populasi kambing di Indonesia pada tahun 2016 mencapai 19.608.000 ekor, 57,46\% diantaranya atau 11.266.272 ekor terdapat di Pulau Jawa, 23,24\% di Pulau Sumatera dan sisanya di pulau lain. Populasi kambing di Indonesia didominasi oleh kambing lokal yaitu kambing Kacang dan Peranakan Ettawah (PE). Kambing Kacang merupakan kambing asli Indonesia yang memiliki tubuh kecil dan pendek, bertelinga tegak dan pendek, berbulu pendek dan berwarna hitam, cokelat dengan campuran putih. Kambing Kacang meiliki sifat adaptif yang baik pada berbagai kondisi lingkungan, kesuburan dan prolifikasi tinggi (Batubara et al. 2006). Kambing PE adalah kambing persilangan antara kambing Ettawah atau dikenal dengan Jamnapari yang berasal dari India dengan kambing Kacang sebagai upaya peningkatan kualitas kambing lokal di Indonesia. Kambing PE memiliki tubuh lebih besar dari kambing Kacang dan merupakan kambing tipe dwiguna dengan kemampuan memproduksi susu dan daging. Kambing PE memiliki ciri-ciri tubuh tinggi dan pipih, telinga panjang dan menggantung, bulu panjang dengan warna dominan putih, garis muka cembung dan garis punggung mengombak (Batubara et al. 2006). Selain kambing Kacang dan PE, masih terdapat beberapa jenis kambing lokal Indonesia yang sudah dikarakterisasi antara lain kambing Kosta (Banten), Gembrong (Bali), Marica (Sulawesi Selatan), Benggala (Nusa Tenggara Timur), Samosir dan Muara (Sumatera Utara) (Batubara et al. 2006).

Data BPS Provinsi Riau (2016) menunjukkan populasi kambing di Kabupaten Bengkalis pada tahun 2016 mencapai 15.553 ekor. Populasi ini merupakan populasi terbanyak ketiga di Provinsi Riau dan populasi tertinggi di wilayah pesisir Provinsi Riau. Kabupaten Bengkalis merupakan salah satu kabupaten yang berada di pesisir wilayah Provinsi Riau yang berbatasan dan memiliki akses langsung dengan negara Malaysia. Secara geografis, wilayah Kabupaten Bengkalis terdiri dari daerah Bengkalis Daratan (berada di daratan Pulau Sumatera) dan wilayah kepulauan. Ternak kambing telah dipelihara di wilayah ini sejak lama turun temurun hingga beberapa generasi beradaptasi dan berkembangbiak hingga saat ini. Pola pemulian ternak masih dilakukan secara tradisional sehingga kemungkinan mengakibatkan terjadinya pencampuran gen antara kambing lokal Kabupaten Bengkalis dengan kambing jenis lain. Sistem pemeliharaannya juga berbeda-beda di tiap daerah dan masing-masing petani baik secara intensif maupun semiintensif. Hal ini diduga mempengaruhi keberagaman kambing lokal yang ada di Kabupaten Bengkalis.

Berdasarkan sifat tersebut, individu ternak dapat dikelompokkan ke dalam beberapa kelompok dan dapat dibedakan antara satu rumpun dengan rumpun yang lainnya. Sifat kualitatif pada kambing yang biasa diamati adalah warna bulu, bentuk tanduk, bentuk telinga, garis muka dan garis punggung. Pada beberapa jenis ternak, sifat tersebut menjadi ciri khusus yang mengelompokkan kambing ke dalam beberapa rumpun.

Untuk melestarikan dan mempercepat peningkatan populasi kambing di Kabupaten Bengkalis, maka langkah awal yang dapat dilakukan adalah dengan mendapatkan informasi dasar tentang karakteristik kualitatif serta keragaman dalam populasi. Informasi tersebut cukup penting untuk menentukan strategi pemuliaan dan sistem pengembangan ternak kambing lokal. Hasil penelitian ini juga diharapkan dapat dijadikan data dasar tentang karakter fenotipik untuk menentukan arah kebijakan konservasi dan perbaikan mutu genetik kambing lokal. Peningkatan populasi dan mutu genetik kambing lokal Kabupaten Bengkalis dengan didukung oleh sumber daya alam dan potensi geografis Kabupaten Bengkalis dapat membantu memenuhi kebutuhan kambing secara nasional dan memanfatkan peluang pemasaran kambing lokal hingga ke mancanegara. 


\section{MATERI DAN METODE}

Penelitian dilakukan di Kabupaten Bengkalis dengan sampel empat kecamatan yang terdiri dari dua kecamatan mewakili wilayah Kabupaten Bengkalis bagian kepulauan (Bantan dan Bengkalis) dan dua kecamatan yang mewakili wilayah Kabupaten Bengkalis bagian daratan (Siak Kecil dan Bukit Batu). Mayoritas peternak di Kecamatan Bantan dan Bengkalis menggunakan sistem pemeliharaan intensif, sedangkan di Kecamatan Siak Kecil dan Bukit Batu menggunakan sistem tradisional. Total sampel kambing yang diamati berjumlah 110 ekor dengan masing-masing jumlah ternak di Kecamatan Bantan sebanyak 31 ekor, Kecamatan Bengkalis 20 ekor, Kecamatan Siak Kecil 22 ekor dan Kecamatan Bukit Batu 37 ekor.

Pengambilan data dilakukan dengan metode survei menggunakan kuisioner dan daftar isian dengan pengelompokkan berdasarkan kecamatan asal ternak. Sifat fenotipe yang diamati adalah warna dominan dan belang serta pola warna yang terdapat pada bagian kepala, leher, badan, kaki dan ekor pada setiap individu. Pengamatan sifat tanduk berdasarkan pada panjang tanduk, bentuk tanduk dan bentuk telinga. Diamati pula garis muka dan garis punggung kambing.

Data yang terkumpul ditabulasi dan dihitung nilai frekuensi relatif dan persentase kelompok sifat terhadap populasi yang dikelompokan berdasarkan daerah asal kambing. Analisis data yang dilakukan adalah deskriptif kualitatif.

\section{HASIL DAN PEMBAHASAN}

\section{Sifat warna bulu}

Berdasarkan hasil pengamatan pola warna bulu (Tabel 1) kambing lokal di empat lokasi pengamatan di Kabupaten Bengkalis ditemukan empat jenis warna yakni hitam, putih, cokelat dan abu-abu. Keempat warna tersebut membentuk pola warna polos, namun sebagian membentuk kombinasi pola warna belang dua warna dan belang tiga warna pada seluruh tubuh maupun pada masing masing anggota tubuh kambing.

Pola warna yang ditemukan pada kambing lokal di Kabupaten Bengkalis adalah delapan pola warna (Tabel 1) dengan pola warna yang paling banyak ditemukan secara keseluruhan anggota tubuh adalah pola warna campuran hitam-cokelat dan selanjutnya adalah campuran tiga warna hitam-putih-cokelat. Untuk masing masing anggota tubuh campuran warna hitam-cokelat paling banyak terdapat pada bagian kepala dan leher, selanjutnya warna campuran hitam-putih-cokelat juga terdapat pada kedua bagian tubuh tersebut. Bagian badan dan kaki paling banyak terdapat campuran tiga warna hitam-putihcokelat lalu diikuti campuran warna hitam-cokelat pada kedua bagian tubuh tersebut. Pada bagian ekor pola warna didominasi oleh warna putih polos dan diikuti dengan campuran warna hitam-cokelat. Pola warna ini berbeda dengan penelitian Ilham (2009) dimana pola warna kambing lokal di Kabupaten Bone Bolango yang paling banyak ditemukan adalah warna hitam polos, selanjutnya adalah warna cokelat polos. Berbeda pula dengan pola warna pada penelitian Wahyuni et al. (2016) pada kambing Kacang di Kabupaten Muna Barat yang menemukan bahwa pola warna yang paling banyak ditemukan adalah cokelat polos lalu diikuti oleh warna hitam polos. Namun, hasil ini mendekati dengan pendapat Batubara et al. (2006) yang menyatakan bahwa kambing Kacang memiliki warna tunggal atau warna yang berasal dari campuran hitam, putih, cokelat. Warna kambing PE jarang ditemukan tunggal tetapi sering ditemukan dua atau tiga pola warna yaitu belang hitam, belang cokelat dan putih totol hitam. Kondisi ini diduga disebabkan oleh banyaknya kambing lokal di Kabupaten Bengkalis yang memiliki gen warna cokelat. Hal ini terlihat 
dari jumlah kambing yang memiliki warna cokelat polos lebih banyak dibandingkan dengan kambing yang memiliki warna hitum polos maupun putih polos.

Kambing lokal dengan warna dominan cokelat paling banyak dibandingkan dengan warna dominan hitam, putih, maupun abu-abu. Terlihat banyak ditemukan pola warna campuran hitam-cokelat. Hal ini sesuai dengan pernyataan Devendra \& Burns (1983) yang menyatakan bahwa warna hitam adalah warna yang predominan pada kambing Kacang dibandingkan dengan warna cokelat dan putih. Hal ini terlihat pada beberapa kambing dalam pengamatan yang memiliki warna dominan hitam akan cenderung memiliki warna polos atau tanpa belang sedangkan kambing yang memiliki warna dominan cokelat yang merupakan warna dominan paling banyak ditemukan akan berkombinasi dengan warna hitam dan putih untuk membentuk pola warna belang dua warna atau tiga warna. Hal tersebut dikuatkan oleh Mulliadi (1996) bahwa kombinasi dan pola warna ditentukan oleh gen-gen berbeda tetapi bekerjasama dengan gen warna dasar.

Tabel 1. Pola warna pada bagian kepala, leher, badan, kaki dan ekor berdasarkan asal kambing

\begin{tabular}{|c|c|c|c|c|c|c|c|c|c|c|}
\hline \multirow{2}{*}{ Warna bulu } & \multicolumn{2}{|c|}{ Bantan } & \multicolumn{2}{|c|}{ Bengkalis } & \multicolumn{2}{|c|}{ Siak Kecil } & \multicolumn{2}{|c|}{ Bukit Batu } & \multicolumn{2}{|c|}{ Total } \\
\hline & $\Sigma$ & $\%$ & $\Sigma$ & $\%$ & $\Sigma$ & $\%$ & $\Sigma$ & $\%$ & $\Sigma$ & $\%$ \\
\hline \multicolumn{11}{|l|}{ Bagian kepala } \\
\hline Hitam polos & 1 & 3,2 & 1 & 5 & 1 & 4,5 & 3 & 8,1 & 6 & 5,5 \\
\hline Putih polos & 0 & 0,0 & 0 & 0 & 1 & 4,5 & 2 & 5,4 & 3 & 2,7 \\
\hline Cokelat polos & 3 & 9,7 & 0 & 0 & 6 & 27,3 & 1 & 2,7 & 10 & 9,1 \\
\hline Campuran hitam-putih & 2 & 6,5 & 1 & 5 & 1 & 4,5 & 0 & 0,0 & 4 & 4,0 \\
\hline Campuran hitam-cokelat & 5 & 16,1 & 9 & 45 & 8 & 36,4 & 20 & 54,1 & 42 & 38,2 \\
\hline Campuran putih-cokelat & 9 & 29,0 & 3 & 15 & 2 & 9,0 & 3 & 8,0 & 17 & 15,0 \\
\hline Campuran hitam-putih-cokelat & 10 & 32,3 & 6 & 30 & 2 & 9,1 & 8 & 21,6 & 26 & 23,6 \\
\hline Campuran abu-abu & 1 & 3,20 & 0 & 0 & 1 & 4,5 & 0 & 0,0 & 2 & 2,0 \\
\hline Total & 31 & 100 & 20 & 100 & 22 & 100 & 37 & 100 & 110 & 100 \\
\hline \multicolumn{11}{|l|}{ Bagian leher } \\
\hline Hitam polos & 1 & 3,2 & 1 & 5 & 1 & 4,5 & 3 & 8,1 & 6 & 5,5 \\
\hline Putih polos & 1 & 3,2 & 0 & 0 & 2 & 9,1 & 2 & 5,4 & 5 & 4,5 \\
\hline Cokelat polos & 4 & 12,9 & 1 & 5 & 5 & 22,7 & 3 & 8,1 & 13 & 11,8 \\
\hline Campuran hitam-putih & 5 & 16,1 & 1 & 5 & 0 & 0,0 & 1 & 2,7 & 7 & 6,0 \\
\hline Campuran hitam-cokelat & 4 & 12,9 & 6 & 30 & 12 & 54,5 & 21 & 56,8 & 43 & 39,1 \\
\hline Campuran putih-cokelat & 7 & 23,0 & 5 & 25 & 1 & 5,0 & 3 & 8,0 & 16 & 15,0 \\
\hline Campuran hitam-putih-cokelat & 7 & 22,6 & 6 & 30 & 0 & 0,0 & 4 & 10,8 & 17 & 15,5 \\
\hline Campuran abu-abu & 2 & 6,5 & 0 & 0 & 1 & 4,5 & 0 & 0,0 & 3 & 3,0 \\
\hline Total & 31 & 100 & 20 & 100 & 22 & 100 & 37 & 100 & 110 & 100 \\
\hline \multicolumn{11}{|l|}{ Bagian Badan } \\
\hline Hitam polos & 1 & 3,2 & 0 & 0 & 1 & 4,5 & 1 & 2,7 & 3 & 27,0 \\
\hline Putih polos & 5 & 16,1 & 3 & 15 & 3 & 13,6 & 4 & 10,8 & 15 & 13,6 \\
\hline Cokelat polos & 4 & 12,9 & 1 & 5 & 4 & 18,2 & 2 & 5,4 & 11 & 10,0 \\
\hline Campuran hitam-putih & 5 & 16,1 & 2 & 10 & 0 & 0,0 & 2 & 5,4 & 9 & 8,0 \\
\hline Campuran hitam-cokelat & 2 & 6,5 & 3 & 15 & 7 & 31,8 & 17 & 45,9 & 29 & 26,4 \\
\hline Campuran putih-cokelat & 5 & 16,0 & 1 & 5 & 1 & 5,0 & 2 & 5,0 & 9 & 8,0 \\
\hline Campuran hitam-putih-cokelat & 9 & 29,0 & 10 & 50 & 5 & 22,7 & 9 & 24,3 & 33 & 30,0 \\
\hline Campuran abu-abu & 0 & 0,0 & 0 & 0 & 1 & 4,5 & 0 & 0,0 & 1 & 1,0 \\
\hline Total & 31 & 100 & 20 & 100 & 22 & 100 & 37 & 100 & 110 & 100 \\
\hline
\end{tabular}


Tabel 1. Pola warna pada bagian kepala, leher, badan, kaki dan ekor berdasarkan asal kambing (lanjutan)

\begin{tabular}{|c|c|c|c|c|c|c|c|c|c|c|}
\hline \multirow{2}{*}{ Warna bulu } & \multicolumn{2}{|c|}{ Bantan } & \multicolumn{2}{|c|}{ Bengkalis } & \multicolumn{2}{|c|}{ Siak Kecil } & \multicolumn{2}{|c|}{ Bukit Batu } & \multicolumn{2}{|c|}{ Total } \\
\hline & $\Sigma$ & $\%$ & $\Sigma$ & $\%$ & $\Sigma$ & $\%$ & $\Sigma$ & $\%$ & $\Sigma$ & $\%$ \\
\hline \multicolumn{11}{|l|}{ Bagian kaki } \\
\hline Hitam polos & 1 & 3,2 & 0 & 0 & 1 & 4,5 & 1 & 2,7 & 3 & 2,7 \\
\hline Putih polos & 3 & 9,7 & 1 & 5 & 3 & 13,6 & 4 & 10,8 & 11 & 10,0 \\
\hline Cokelat polos & 5 & 16,1 & 2 & 10 & 9 & 40,9 & 4 & 10,8 & 20 & 18,2 \\
\hline Campuran hitam-putih & 3 & 9,7 & 1 & 5 & 0 & 0,0 & 3 & 8,1 & 7 & 6,0 \\
\hline Campuran hitam-cokelat & 2 & 6,5 & 3 & 15 & 4 & 18,2 & 14 & 37,8 & 23 & 20,9 \\
\hline Campuran putih-cokelat & 6 & 19,0 & 5 & 25 & 3 & 14,0 & 6 & 16,0 & 20 & 18,0 \\
\hline Campuran hitam-putih-cokelat & 10 & 32,3 & 8 & 40 & 1 & 4,5 & 5 & 13,5 & 25 & 21,8 \\
\hline Campuran abu-abu & 1 & 3,2 & 0 & 0 & 1 & 4,5 & 0 & 0,0 & 2 & 2,0 \\
\hline Total & 31 & 100 & 20 & 100 & 22 & 100 & 37 & 100 & 110 & 100 \\
\hline \multicolumn{11}{|l|}{ Bagian ekor } \\
\hline Hitam polos & 5 & 16,1 & 1 & 5 & 1 & 4,5 & 7 & 18,9 & 14 & 12,7 \\
\hline Putih polos & 14 & 45,2 & 9 & 45 & 5 & 22,7 & 6 & 16,2 & 34 & 30,9 \\
\hline Cokelat polos & 5 & 16,1 & 2 & 10 & 4 & 18,2 & 2 & 5,4 & 13 & 11,8 \\
\hline Campuran hitam-putih & 2 & 6,5 & 0 & 0 & 1 & 4,5 & 0 & 0,0 & 3 & 3,0 \\
\hline Campuran hitam-cokelat & 1 & 3,2 & 7 & 35 & 9 & 40,9 & 3 & 8,1 & 20 & 18,2 \\
\hline Campuran putih-cokelat & 4 & 13,0 & 0 & 0 & 1 & 5,0 & 13 & 35,0 & 18 & 16,0 \\
\hline Campuran hitam-putih-cokelat & 0 & 0,0 & 1 & 5 & 0 & 0,0 & 6 & 16,2 & 7 & 6,04 \\
\hline Campuran abu-abu & 0 & 0,0 & 0 & 0 & 1 & 4,5 & 0 & 0,0 & 1 & 1,0 \\
\hline Total & 31 & 100 & 20 & 100 & 22 & 100 & 37 & 100 & 110 & 100 \\
\hline
\end{tabular}

Apabila dilihat dari masing-masing daerah sampel, maka secara umum seluruh anggota tubuh kecuali ekor kambing lokal di kecamatan Bantan dan Bengkalis sering ditemukan pola warna campuran hitam-putih-cokelat, pola warna selanjutnya untuk kecamatan Bantan adalah putih-cokelat dan Kecamatan Bengkalis hitam-cokelat. Di Kecamatan Siak Kecil dan Bukit Batu pola warna yang sering ditemukan adalah samasama campuran hitam-cokelat. Selanjutnya untuk Kecamatan Siak Kecil adalah pola warna cokelat polos dan Kecamatan Bukit Batu adalah campuran hitam-putih-cokelat. Pada ternak kambing, pigmen yang mengatur warna tubuh terdiri dari pigmen eumelamin dan pheomelamin. Pheomelamin bertanggung jawab untuk terjadinya warna tan, krim dan merah. Sementara pigmen eumelamin bertanggung jawab untuk terjadinya warna black bluegreen dan chocolate brown. Sementara penutup tubuh warna putih merupakan yang tidak berpigmen.

Kesamaan pola warna yang paling banyak ditemukan antara Kecamatan Bantan dengan Bengkalis serta antara Kecamatan Siak Kecil dengan Bukit Batu diduga dipengaruhi oleh letak geografis wilayah tersebut, dimana Kecamatan Bantan dan Bengkalis berada pada wilayah Pulau Bengkalis sedangkan Kecamatan Siak Kecil dan Bukit Batu masuk ke wilayah Kabupaten Bengkalis bagian daratan Pulau Sumatera dan dipisahkan oleh wilayah perairan Selat Bengkalis. Hal ini terkait dengan mobilitas ternak yang mempengaruhi pewarisan sifat fenotipik dalam artian kambing yang berada di suatu kecamatan kemungkinan besar dapat berpindah ke kecamatan lain yang berada pada satu pulau dikarenakan jual beli ternak bakalan atau peminjaman pejantan seperti yang sering terjadi di masyarakat. Sementara untuk pemindahan ternak antar kecamatan yang berada 
pada pulau yang berlainan memiliki kemungkinan yang sangat kecil dikarenakan efektivitas dan alasan keamanan kesehatan ternak.

Pola warna belang hitam-putih-cokelat yang paling banyak ditemukan pada kambing lokal di wilayah Kecamatan Bantan dan Bengkalis diduga akibat adanya interaksi sifat warna putih yang merupakan warna yang banyak ditemukan pada kambing PE, sebagaimana menurut Rasminati (2013) bahwa warna putih merupakan warna umum kambing PE yang mendomestikasi. Didukung oleh kesukaan masyarakat peternak di Kecamatan Bantan dan Bengkalis terhadap kambing yang memiliki ukuran tubuh besar seperti kambing jenis PE atau sering dikenal dengan sebutan kambing Koplo oleh masyarakat di Kecamatan Bantan. Dengan demikian peternak mengawinkan kambing betina yang bertubuh kecil dengan kambing jantan yang bertubuh besar. Sedangkan pola warna campuran hitam-cokelat di Kecamatan Siak Kecil dan Bukit Batu menyerupai warna kambing lokal secara umum di Kabupaten Bengkalis. Menurut Dyantari et al. (2015) sifat menurun warna putih pada kambing Gembrong adalah dominan secara autosomal terhadap warna cokelat atau gen yang menentukan warna bulu kambing Gembrong terdapat pada autosom atau tidak pada kromosom seks X maupun Y. Diduga kambing lokal di Kabupaten Bengkalis juga mengikuti pola penurunan sifat warna bulu kambing Gembrong dan terjadi interaksi antara gen penentu warna bulu dari masingmasing tetua.

Hasil penelitian Inounu et al. (2009) pada domba dengan penampakan umum warna putih yang ditentukan oleh lokus agouti yang meliputi lima kelompok fenotipe yaitu white atau tan, wild, badgerface, light badgerface, black dan tan kemudian disertakan pula dengan penampakan yang khusus untuk masing-masing fenotipe. Menurut pendapat Fontanesi et al. (2009) warna bulu mamalia ditentukan oleh distribusi dua jenis pigmen melanin, yakni eumelanin yang berkaitan dengan warna hitam atau cokelat dan pheomelanin yang berkaitan dengan warna merah atau kuning dimana jumlahnya dikendalikan oleh lokus agouti dan ekstension. Alel dominan pada lokus ekstensi akan membentuk warna bulu hitam, sedangkan alel resesif menghasilkan pigmentasi merah atau kuning. Di sisi lain, alel dominan di lokus agouti menghasilkan pigmentasi pheomelanin, sedangkan alel resesif menyebabkan warna hitam seragam. Terdapat beberapa gen yang diduga berkaitan dengan warna bulu kambing sehingga belum dapat dipastikan gen apa yang menentukan warna bulu kambing (Badaoui et al. 2011). Salah satu gen tersebut adalah caprine agouti yang telah dianalisis oleh beberapa peneliti (Fontanesi et al. 2009; Li et al. 2010; Badaoui et al. 2011; Akis et al. 2012). Tidak ada hubungan yang jelas antara polimorfisme gen caprine agouti yang terdeteksi dengan fenotipe warna bulu bangsa kambing Italia dan Spanyol (Badaoui et al. 2011) serta kambing lokal Turki (Akis et al. 2012).

Pola warna dominan adalah warna dasar yang memiliki luasan paling besar pada individu ternak kambing sedangkan warna belang adalah warna yang memiliki luasan lebih kecil dibandingkan dengan warna dominan. Warna dominan biasanya hanya terdiri dari satu warna saja dan warna belang bisa terdiri dari satu warna atau lebih. Kombinasi warna pada kambing antar warna dominan dan warna belang cukup beragam, dapat hanya berupa warna dominan sendiri maupun berkolaborasi dengan warna belang.

Hasil pengamatan (Tabel 2) menunjukkan bahwa warna bulu dominan yang terdapat pada kambing lokal yang ada di Kabupaten Bengkalis adalah hitam, cokelat, putih dan abu-abu. Warna dominan yang paling banyak ditemukan pada seluruh kambing sampel adalah warna cokelat dengan persentase lebih dari setengah populasi. Selanjutnya adalah warna putih, diikuti dengan warna hitam lalu terakhir adalah warna abu-abu. Warna dominan cokelat yang banyak ditemukan ini menunjukkan bahwa sebagian besar pola warna kambing lokal di Kabupaten Bengkalis cenderung mengikuti pola warna kambing 
Kacang seperti pada penelitian Hoda (2008) pada kambing Kacang di Maluku Utara yang sebagian besar memiliki pola warna dominan cokelat. Untuk pola warna dominan putih yang jumlahnya lebih banyak daripada warna dominan hitam dan abu-abu mendekati warna dominan kambing PE sesuai dengan pendapat Rasminati (2013) yang menyatakan bahwa pada kambing PE warna putih dominan terhadap warna hitam dan cokelat.

Tabel 2. Warna dominan dan warna belang kambing lokal di Kabupaten Bengkalis

\begin{tabular}{|c|c|c|c|c|c|c|c|c|c|c|}
\hline \multirow{2}{*}{ Warna bulu } & \multicolumn{2}{|c|}{ Bantan } & \multicolumn{2}{|c|}{ Bengkalis } & \multicolumn{2}{|c|}{ Siak Kecil } & \multicolumn{2}{|c|}{ Bukit Batu } & \multicolumn{2}{|c|}{ Total } \\
\hline & $\Sigma$ & $\%$ & $\Sigma$ & $\%$ & $\Sigma$ & $\%$ & $\Sigma$ & $\%$ & $\Sigma$ & $\%$ \\
\hline \multicolumn{11}{|l|}{ Warna dominan } \\
\hline Hitam & 5 & 16,1 & 0 & 0 & 1 & 4,5 & 5 & 13,5 & 11 & 10,0 \\
\hline Putih & 14 & 45,2 & 8 & 40 & 5 & 22,7 & 6 & 16,2 & 33 & 30,0 \\
\hline Cokelat & 12 & 38,7 & 12 & 60 & 15 & 68,2 & 26 & 70,3 & 65 & 59,1 \\
\hline Abu-abu & 0 & 0,0 & 0 & 0 & 1 & 5,0 & 0 & 0,0 & 1 & 0,9 \\
\hline Total & 31 & 100 & 20 & 100 & 22 & 100 & 37 & 100 & 110 & 100 \\
\hline \multicolumn{11}{|l|}{ Warna belang } \\
\hline Hitam & 7 & 22,6 & 5 & 25 & 8 & 36,4 & 14 & 37,8 & 34 & 30,9 \\
\hline Putih & 5 & 16,1 & 1 & 5 & 0 & 0,0 & 5 & 13,5 & 11 & 10,0 \\
\hline Cokelat & 3 & 9,7 & 1 & 5 & 2 & 9,1 & 3 & 8,1 & 9 & 8,2 \\
\hline Hitam-putih & 1 & 3,2 & 7 & 35 & 5 & 22,7 & 7 & 18,9 & 20 & 18,2 \\
\hline Hitam-cokelat & 6 & 19,4 & 5 & 25 & 2 & 9,1 & 3 & 8,1 & 16 & 14,5 \\
\hline Putih-cokelat & 3 & 9,7 & 0 & 0 & 0 & 0,0 & 0 & 0,0 & 3 & 2,7 \\
\hline Tanpa belang & 4 & 12,9 & 1 & 5 & 4 & 18,2 & 2 & 5,4 & 11 & 10,0 \\
\hline Abu-abu & 2 & 6,0 & 0 & 0 & 1 & 5,0 & 3 & 8,0 & 6 & 5,0 \\
\hline Total & 31 & 100 & 20 & 100 & 22 & 100 & 37 & 100 & 110 & 100 \\
\hline
\end{tabular}

Berdasarkan wilayah sampel Kecamatan Bantan memiliki warna dominan putih paling banyak dengan perbedaan persentase yang sangat sedikit dengan warna dominan cokelat yang merupakan warna dominan kedua terbanyak. Warna dominan putih ini diduga disebabkan adanya pengaruh gen warna putih dari kambing PE yang ada di wilayah Kecamatan Bengkalis. Menurut masyarakat di Kecamatan Bantan pernah dilakukan introduksi kambing PE yang berwarna putih beberapa tahun yang lalu, akan tetapi kurang mampu beradaptasi dengan lingkungan. Namun beberapa peternak pernah melakukan perkawinan antara kambing PE dengan kambing Kacang sehingga ada kemungkinan kambing lokal yang memiliki warna dominan putih adalah keturunan dari kambing PE. Pola warna dominan di tiga kecamatan lain masing-masing adalah cokelat lalu diikuti dengan warna dominan putih dengan selisih persentase yang cukup besar. Warna dominan hitam ditemukan pada kambing sampel di tiga kecamatan dan tidak ditemukan pada kambing sampel di Kecamatan Bengkalis. Kambing dengan warna dominan abu-abu hanya ditemukan di Kecamatan Siak Kecil.

Ditemukan delapan pola warna belang yang terdapat pada kambing lokal di Kabupaten Bengkalis (Tabel 2). Warna Belang yang umum ditemukan pada keseluruhan kambing sampel adalah warna hitam, selanjutnya campuran warna hitam-putih lalu campuran hitam-cokelat. Warna hitam maupun kombinasinya merupakan warna yang sering ditemukan pada kambing sampel. Hasil ini berkaitan dengan pendapat Devendra \& Burns (1983) yang menyatakan bahwa warna hitam adalah warna predominan terhadap 
warna cokelat dan putih pada kambing Kacang. Pada kambing lokal di Kabupaten Bengkalis, warna hitam tidak banyak muncul sebagai warna dominan, akan tetapi banyak ditemukan sebagai warna belang. Didukung oleh pendapat Rasminati (2013) yang menemukan banyak warna hitam sebagai warna belang pada bagian kepala dan leher kambing PE. Warna bulu hitam yang umum ditemukan pada kambing lokal di Kabupaten Bengkalis berada pada bagian muka, garis punggung mulai dari leher hingga ekor, mendekati pola warna kambing Kacang pada penelitian Hoda (2008) yang memiliki garis punggung hitam. Beberapa kambing bahkan membentuk kalung mengikuti batas antara badan dan pangkal leher kearah bawah dan semakin membesar menutupi bagian dada. Pola warna khas ini banyak ditemukan pada kambing yang memiliki ciri-ciri seperti kambing Kacang, terutama yang berwarna dominan cokelat. Sementara pada kambing yang memiliki ciri-ciri seperti kambing PE, warna hitam banyak ditemukan pada bagian kepala hingga leher. Secara umum masing-masing lokasi sampel memiliki pola warna belang terbanyak berwarna hitam, hanya di kecamatan Bengkalis paling banyak ditemukan warna belang Hitam-Putih.

\section{Sifat bentuk tanduk dan tipe telinga}

Pada hasil pengamatan (Tabel 3) seluruh kambing sampel memiliki tanduk, hampir sama dengan penelitian Hoda (2008) pada kambing Kacang, Ilham (2009) pada kambing lokal di Bone-Bolango dan Wahyuni et al. (2016) pada kambing Kacang yang hampir keseluruhan kambing memiliki tanduk. Bentuk tanduk yang ditemukan beragam, yakni berbentuk tonjolan, lurus ke atas, melengkung ke atas dan melengkung ke belakang. Bentuk tanduk yang paling umum ditemukan adalah melengkung ke atas, pada pangkal tanduk hingga mendekati ujung berbentuk lurus lalu sedikit melengkung pada bagian ujungnya. Bentuk tanduk terbanyak berikutnya adalah lurus ke atas, dari pangkal tanduk hingga ujungnya berbentuk lurus meruncing ke bagian atas sejajar gari muka. Selanjutnya adalah bentuk tonjolan tanduk dan yang paling sedikit ditemukan adalah tanduk yang melengkung ke belakang dari pangkal tanduk dan cenderung mengarah ke bawah pada ujungnya. Menurut Batubara et al. (2006) kambing Kacang memiliki bentuk tanduk melengkung ke atas sampai ke belakang dan ujung tanduk kambing PE agak melengkung ke belakang. Sementara menurut Rasminati (2013) tanduk kambing PE melengkung ke belakang mengitari telinga. Bentuk tanduk pada kambing lokal di Kabupaten Bengkalis mendekati ciri-ciri bentuk tanduk kambing Kacang dan PE. Bentuk tanduk berupa tonjolan diduga akibat kambing mempunyai gen dominan sebagaimana pendapat Hoda (2008), Indrijani et al. (2006) sifat bertanduk diketahui sebagai gen resesif. Dengan adanya bentuk tanduk yang berupa benjolan maka ekspresi sifat bertanduk pada kambing lokal di Kabupaten Bengkalis terhambat oleh gen dominan, karena pertumbuhan tanduk tidak sempurna.

Berdasarkan wilayah sampel, Kecamatan Bantan dan Bengkalis sama-sama banyak ditemukan kambing dengan tanduk melengkung ke atas, sedangkan di Kecamatan Siak Kecil dan Bukit Batu kebanyakan tanduk kambing berbentuk lurus ke atas. Khusus untuk Kecamatan Bengkalis, kambing yang memiliki tanduk berbentuk melengkung ke atas dan melengkung ke belakang sama banyak. Keseragaman ini diduga akibat letak geografis wilayah yang berkaitan dengan keterbatasan perpindahan ternak. Bentuk tanduk lurus ke atas pada kambing yang banyak ditemukan di Kecamatan Bukit Batu dan Siak Kecil lebih mendekati sifat kambing Kacang yang memiliki tanduk melengkung ke atas.

Sebagian besar kambing lokal di Kabupaten Bengkalis (Tabel 3) memiliki bentuk telinga tegak, selanjutnya setengah terkulai lalu sebagian kecil terkulai. Hasil ini mendekati hasil penelitian Wahyuni et al. (2016) pada kambing Kacang yang menemukan 
kambing dengan telinga setengah terkulai paling banyak selanjutnya bentuk telinga yang ditemukan setengah menjuntai dan tidak menemukan kambing dengan bentuk telinga terkulai. Sementara penelitian Ilham (2009) menemukan kambing lokal di Bone Bolango dengan bentuk telinga terkulai dan bentuk setengah terkulai dengan jumlah paling banyak, namun tidak ditemukan kambing dengan bentuk telinga tegak.

Tabel 3. Sifat kualitatif bentuk tanduk dan tipe telinga kambing lokal di Kabupaten Bengkalis

\begin{tabular}{|c|c|c|c|c|c|c|c|c|c|c|}
\hline \multirow{2}{*}{ Sifat } & \multicolumn{2}{|c|}{ Bantan } & \multicolumn{2}{|c|}{ Bengkalis } & \multicolumn{2}{|c|}{ Siak Kecil } & \multicolumn{2}{|c|}{ Bukit Batu } & \multicolumn{2}{|c|}{ Total } \\
\hline & $\Sigma$ & $\%$ & $\Sigma$ & $\%$ & $\Sigma$ & $\%$ & $\Sigma$ & $\%$ & $\Sigma$ & $\%$ \\
\hline \multicolumn{11}{|l|}{ Bentuk tanduk } \\
\hline Tonjolan & 9 & 29,0 & 3 & 15 & 5 & 22,7 & 7 & 18,9 & 24 & 21,8 \\
\hline Melengkung ke atas & 13 & 41,9 & 7 & 35 & 6 & 27,3 & 12 & 32,4 & 38 & 34,5 \\
\hline Melengkung ke belakang & 5 & 16,1 & 7 & 35 & 2 & 9,1 & 5 & 13,5 & 19 & 17,3 \\
\hline Lurus ke atas & 4 & 12,9 & 3 & 15 & 9 & 40,9 & 13 & 35,1 & 29 & 26,4 \\
\hline Total & 31 & 100 & 20 & 100 & 22 & 100 & 37 & 100 & 110 & 100 \\
\hline \multicolumn{11}{|l|}{ Bentuk telinga } \\
\hline Terkulai & 9 & 29,0 & 9 & 45 & 4 & 18,2 & 6 & 16,2 & 28 & 25,5 \\
\hline Setengah terkulai & 14 & 45,2 & 9 & 45 & 3 & 13,6 & 6 & 16,2 & 32 & 29,1 \\
\hline Tegak & 8 & 25,8 & 2 & 10 & 15 & 68,2 & 25 & 67,6 & 50 & 45,5 \\
\hline Total & 31 & 100 & 20 & 100 & 22 & 100 & 37 & 100 & 110 & 100 \\
\hline
\end{tabular}

Kambing lokal di Kabupaten Bengkalis memiliki tipe telinga antara kambing PE yang memiliki telinga lembek menggantung (Batubara et al. 2006) dan menempel ke muka (Rasminati 2013) dengan kambing Kacang yang memiliki telinga pendek, sampai menggantung (Batubara et al. 2006). Menurut penelitian Sutiyono et al. (2006) pada kambing PE di Kabupaten Kendal kambing yang memiliki telinga panjang menyerupai kambing Ettawah sebanyak 86,78 dan 13,22\% memiliki telinga pendek menyerupai kambing Kacang. Pada wilayah sampel Kecamatan Bengkalis antara bentuk telinga terkulai dengan setengah terkulai memiliki proporsi yang sama besar, karena di Kecamatan Bengkalis dan Bantan yang masih berada pada satu pulau pernah diintroduksikan kambing PE. Diduga sifat kambing PE masih bertahan dan disukai peternak. Sementara di Kecamatan Bukit Batu dan Siak Kecil banyak ditemukan kambing bertipe telinga tegak dan sedikit kambing yang bertelinga terkulai menyerupai kambing PE. Diduga keturunan kambing PE di kedua kecamatan tersebut sudah mulai berkurang dikarenakan kambing PE kurang adaptif dibandingkan dengan kambing Kacang, mengingat peternak mayoritas menggunakan sistem pemeliharaan semi-ekstensif.

Menurut Geisen et al. (2008); Kanzler et al. (1998); Kutejova et al. (2008); Lampe et al. (2008) dan Santagati et al. (2005) perkembangan telinga dipengaruhi oleh gen SIX 2. Morfogenesis telinga dipengaruhi oleh gen WNT5A (Donaldson et al. 2012). Sedangkan pada penelitian (Brito et al. 2017) yang meneliti tentang keragaman genetik sembilan jenis kambing yang memiliki telinga pendek (La Mancha), sedang (Alpine, Cashmire, Rangeland, Saanen dan Tonggenburg) serta panjang (Nubian dan Boer) diduga perkembangan telinga kambing dipengaruhi oleh gen CXCL14 dan morfogenesis telinga kambing dipengaruhi oleh gen POU4F3. Mengingat bentuk telinga kambing lokal di Kabupaten Bengkalis menyerupai dua bentuk telinga kambing yang diteliti oleh Brito et al. (2017) diduga ada pengaruh salah satu jenis gen diatas yang mempengaruhi bentuk dan ukuran kambing yang diamati. 


\section{Sifat garis muka dan garis punggung}

Berdasarkan Tabel 4 ditemukan garis muka rata dan cembung pada kambing lokal di Kabupaten Bengkalis dengan garis muka rata paling banyak ditemukan namun ada beberapa kambing mempunyai garis muka cembung. Hasil ini sesuai dengan penelitian Hoda (2008) pada kambing Kacang dan Ilham (2009) pada kambing lokal di Bone Bolango yang menemukan lebih banyak kambing yang memiliki garis muka rata dibandingkan dengan kambing yang memiliki garis muka cembung yang merupakan ciri kambing PE (Batubara et al. 2006; Rasminati 2013). Garis muka cembung paling banyak ditemukan di Kecamatan Bantan, disebabkan keturunan kambing PE cukup banyak ditemukan di daerah ini mengingat jenis kambing ini disukai oleh peternak dan sistem pemeliharaan yang intensif yang lebih sesuai dengan kambing PE.

Tabel 4. Sifat kualitatif garis muka dan garis punggkung kambing lokal di Kabupaten Bengkalis

\begin{tabular}{lrrrrrrrrrr}
\hline \multirow{2}{*}{ Sifat } & \multicolumn{2}{c}{ Bantan } & \multicolumn{2}{c}{ Bengkalis } & \multicolumn{2}{c}{ Siak Kecil } & \multicolumn{2}{c}{ Bukit Batu } & \multicolumn{2}{c}{ Total } \\
\cline { 2 - 12 } & \multicolumn{1}{c}{$\Sigma$} & $\%$ & $\Sigma$ & $\%$ & $\Sigma$ & $\%$ & $\Sigma$ & $\%$ & $\Sigma$ & $\%$ \\
\hline Garis muka & & & & & & & & & & \\
Rata & 26 & 87,1 & 18 & 90 & 22 & 100 & 35 & 94,6 & 102 & 92,7 \\
Cembung & 5 & 12,9 & 2 & 10 & 0 & 0 & 2 & 5,4 & 8 & 7,3 \\
\hline Total & 31 & 100 & 20 & 100 & 22 & 100 & 37 & 100 & 110 & 100 \\
\hline Garis punggung & & & & & & & & & & \\
Rata & 24 & 77,4 & 18 & 90 & 22 & 100 & 37 & 100 & 101 & 91,8 \\
$\quad$ Mengombak & 7 & 22,6 & 2 & 10 & 0 & 0 & 0 & 0 & 9 & 8,2 \\
\hline Total & 31 & 100 & 20 & 100 & 22 & 100 & 37 & 100 & 110 & 100 \\
\hline
\end{tabular}

Garis punggung yang paling banyak ditemukan pada kambing lokal di Kabupaten Bengkalis adalah berbentuk rata dibandingkan dengan mengombak. Hal ini sesuai dengan hasil penelitian Ilham (2009) pada kambing lokal di Bone Bolango dengan keseluruhan kambing yang ditemukan memiliki garis punggung rata. Sementara penelitian terhadap kambing Kacang dilakukan oleh Hoda (2008) menemukan kambing Kacang dan kambing lokal Kejobong memiliki garis punggung paling banyak adalah cekung, akan tetapi masih ditemukan kambing dengan garis punggung rata. Garis punggung mengombak yang didapati di wilayah Kecamatan Bantan dan Bengkalis lebih mengarah kepada bentuk garis punggung kambing PE, sebagaimana pendapat Batubara et al. (2011) bahwa garis punggung kambing PE adalah mengombak kebelakang.

\section{KESIMPULAN}

Dari hasil penelitian ini dapat disimpulkan bahwa kambing lokal yang ada di Kabupaten Bengkalis memiliki sifat kualitatif yang menyerupai kambing Kacang dan kambing Peranakan Ettawah. Berdasarkan wilayah sampel di Kecamatan Siak Kecil dan Bukit Batu maka kambing lokal memiliki sifat kualitatif cenderung menyerupai kambing Kacang, sedangkan di Kecamatan Bantan dan Bengkalis masih memiliki ciri-ciri gabungan antara kambing Kacang dan PE. Perbedaan sifat kualitatif antar wilayah lokasi pengamatan lebih dipengaruhi oleh sistem pemeliharaan dan tingkat kesukaan masyarakat peternak. 


\section{DAFTAR PUSTAKA}

Akis, Iraz, Oztabak K, Gursel FE, Un C. 2012. Goat Agouti gene polymorphism and its association with coat color in indigenous Turkish goat breeds. Vet Med Zoot. 60:3-6.

Badaoui B, D'Andrea M, Pilla F, Capote J, Zidi A, Jordana J, Ferrando A, Delgado JV, Martinez A, Vidal O, Amills M. 2011. Polymorphism of the goat Agouti signaling protein gene and its relationship with coat color in Italian and Spanish breeds. Biochem Genet. 49:523-532.

Batubara A, Doloksaribu M, Tiesnamurti B. 2006. Potensi keragaman sumberdaya genetik kambing lokal Indonesia. Dalam: Lokakarya Nasional Pengelolaan dan Perlindungan Sumber Daya Genetik di Indonesia: Manfaat Ekonomi untuk Mewujudkan Ketahanan Nasional. Bogor, 20 Desember 2016. Bogor (Indonesia): Puslitbangnak. hlm. 206-14.

BPS. 2016. Populasi kambing menurut provinsi 2009-2016 [Internet]. Jakarta (Indonesia): Badan Pusat Statistik. Tersedia dari: www.bps.go.id/linkTableDinamis/view/id/1022

BPS Provinsi Riau. 2016. Provinsi Riau dalam angka 2016. Pekanbaru (Indonesia): Badan Pusat Statistik Provinsi Riau.

Brito LF, Kijas JW, Ventura RV, Sargolzaei M, Porto-Neto LR, Cánovas A, Feng Z, Jafarikia M, Schenkel1 FS. 2017. Genetic diversity and signatures of selection in various goat breeds revealed by genome-wide SNP markers. BMC Genomics. 18:229.

Devendra C, Burns M. 1983. Goat production in the tropics. Slough (UK): CAB, Farnham House.

Donaldson IJ, Amin S, Hensman JJ, Kutejova E, Rattray M, Lawrence N, Hayes A, Ward CM, Bobola N. 2012. Genome-wide occupancy links Hoxa2 to Wnt- $\beta$-catenin signaling in mouse embryonic development. Nucleic Acids Res. 40:3990-4001.

Dyantari KDP, Oka IGL, Warmadewi DA. 2015. Penurunan sifat warna bulu putih dan cokelat pada kambing Gembrong. J Peternakan Tropika. 3:121-132.

Fontanesi L, Beretti F, Riggio V, Gonzalez EG, Dall'Olio S, Davoli R, Russo V, Portolano B. 2009. Copy number variation and missense mutations of the agouti signaling protein (ASIP) gene in goat breeds with different coat colors. Cytogenet Genome Res. 126:333-347.

Geisen, Marc J, Thomas Di Meglio, Massimo Pasqualetti, and Sebastien Ducret. 2008. Hox paralog group 2 genes control the migration of mouse pontine neurons through slit-robo signaling. PLoS Biology. 6:e142.

Hoda A. 2008. Studi karakterisasi, produktivitas dan dinamika populasi kambing Kacang [Disertasi]. [Bogor (Indonesia)]: Institut Pertanian Bogor.

Ilham F. 2009. Characteristics of phenotype trait qualitative and quantitative goat local. 41-50.

Indrijani, Heni, Sukmasari AH, Handiwirawan E. 2006. Keragaman pola warna tubuh, tipe telinga dan tanduk domba kurban di Bogor. 236-44.

Inounu I, Mulyono RH, Ambarawati D. 2009. Pola warna bulu pada domba Garut dan persilangannya. JITV. 14:118-130.

Kanzler, Benoît, Kuschert SJ, Liu Y, Mallo M. 1998. Hoxa-2 restricts the chondrogenic domain and inhibits bone formation during development of the branchial area. Development. $125: 2587-2597$.

Kutejova E, Engist B, Self M, Oliver G, Kirilenko P, Bobola N. 2008. Six2 functions redundantly immediately downstream of Hoxa2. Development. 135:1463-1470.

Lampe X, Samad OA, Guiguen A, Matis C, Remacle S, Picard JJ, Rijili FM, Rezsohary R. 2008. An ultraconserved Hox-Pbx responsive element resides in the coding sequence of Hoxa2 and is active in rhombomere 4. Nucleic Acids Res. 36:3214-3225.

Li X, Zhao J, Tang C, Zhou R, Zheng G, Li L, Guo X. 2010. Sequencing of part of the goat Agouti Gene. Biochem Genet. 48:152-156. 
Mulliadi D. 1996. Sifat fenotipik domba Priangan di Kabupaten Pandeglang dan Garut [Disertasi]. [Bogor (Indonesia)]: Institut Pertanian Bogor.

Rasminati N. 2013. Grade kambing Peranakan Ettawah pada kondisi wilayah yang berbeda. Sains Peternakan. 11:43-48.

Santagati F, Minoux M, Ren S, Rijli FM. 2005. Temporal requirement of Hoxa2 in cranial neural crest skeletal morphogenesis. Development. 132:4927-4936.

Sutiyono B, Widyani NJ, Purbowati E. 2006. Studi performa induk kambing Peranakan Ettawah berdasarkan jumlah anak sekelahiran di Desa Banyuringin, Kecamatan Singosari, Kabupaten Kendal. Dalam: Mathius IW, Sendow I, Nurhayati, Murdiati TB, Thalib A, Beriajaya, Prasetyo LH, Darmono, Wina E, penyunting. Cakrawala Baru IPTEK Menunjang Revitalisasi Peternakan. Prosiding Seminar Nasional Teknologi Peternakan dan Veteriner. Bogor, 5-6 September 2006. Bogor (Indonesia): Puslitbangnak. hlm. 537-543.

Wahyuni V, Nafiu L, Pagala MA. 2016. Karakteristik fenotipe kualitatif dan kuantitatif kambing Kacang di Kabupaten Muna Barat. JITRO. 1:144-156.

\section{DISKUSI}

\section{Pertanyaan}

1. Apa alasan mengambil seampel di empat kecamatan dari delapan kecamatan di Kabupaten Bengkalis?

2. Kapan waktu pelaksanaan penelitian dan apakah program dari Loka Penelitian Kambing Potong?

3. Apakah ada penelitian lain yang pernah dilakukan di Kabupaten Bengkalis tentang jenis kambing terutama mengenai sifat kuantitatif kambing lokal?

4. Mengapa kambing lokal di Kabupaten Bengkalis dihubungkan dengan kambing Kacang dan kambing PE?

\section{Jawaban}

1. Latar belakang penelitian ini adalah untuk membandingkan kambing yang ada di wilayah Kabupaten Bengkalis daratan dan wilayah kabupaten kepulauan. Jadi alasan mengambil data di Kecamatan Bantan dan Bengkalis adalah untuk mewakili wilayah Kabupaten Bengkalis yang berada di wilayah kepulauan, sedangkan Kecamatan Siak Kecil dan Bukit Batu digunakan sebagai wilayah sampel mewakili wilayah Kabupaten Bengkalis yang ada di wilayah daratan. Keempat kecamatan tersebut memiliki populasi kambing yang lebih banyak.

2. Penelitian dilaksanakan pada bulan Mei 2017 dan penelitian ini merupakan penelitian pribadi dan bukan merupakan penelitian program Loka Penelitian Kambing Potong

3. Kami belum menemukan referensi atau hasil penelitian tentang sifat kuantitatif kambing lokal di Kabupaten Bengkalis begitu juga dengan sifat kualitatif kambing lokal di Kabupaten Bengkalis. Sehingga perlu dilakukan penelitian lanjutan untuk melihat sifat kauantitatif kambing.

4. Karena ciri-ciri kambing lokal yang ada di Kabupaten Bengkalis memiliki kemiripan dengan kambing PE dan kambing Kacang. Selain itu di Kabupaten Bengkalis pernah dilakukan introduksi kambing PE sehingga diduga ada pengaruh kambing Kacang dan kambing PE pada kambing lokal di Kabupaten Bengkalis. 